Proc. Estonian Acad. Sci. Geol., 2002, 51, 1, 16-32

\title{
Revision of aeromagnetic data: ground magnetic investigations of altered sedimentary rocks (Hatrurim basin, Israel)
}

\author{
Boris Khesin and Sophia Itkis
}

Department of Geological and Environmental Sciences, Ben-Gurion University of the Negev, P.O.B. 653, Beer-Sheva 84105, Israel; khesin@ bgumail.bgu.ac.il

Received 6 February 2001, in revised form 18 June 2001

\begin{abstract}
Aeromagnetic survey revealed two local anomalies with a magnitude of up to $20 \mathrm{nT}$ within the Hatrurim basin, where altered sedimentary (mainly carbonaceous) rocks of the Hatrurim Formation subjected to combustion metamorphism (CM) are widespread. Aeromagnetic data analysis and ground magnetic prospecting show that the CM model cannot relate all the magnetic characteristics. On one hand, high-amplitude (up to $4000 \mathrm{nT}$ ) high-wave number ground anomalies could be a by-product of the combustion (surface) metamorphism. On the other hand, poor correlation between magnetic susceptibility $(\chi)$ values (reached up to $4000 \times 10^{-5}$ un. SI) and metamorphic grade of Hatrurim Formation rocks, between magnetic anomalies and/or metamorphic grade/thickness of the rocks may suggest involvement of an additional source or presence of high remanent magnetization.
\end{abstract}

Key words: magnetic prospecting, altered sedimentary rocks, combustion metamorphism, Hatrurim basin, Israel.

\section{INTRODUCTION}

Aeromagnetic anomalies at the combustion metamorphism (CM) areas are known only in the Hatrurim basin (Negev region, Israel) and Venezuela (Cisowski \& Fuller 1987). We performed interpretation of aeromagnetic data, detailed ground measurements of total magnetic field $(T)$ and magnetic susceptibility $(\chi)$ in parallel with geological study of S. Feinstein, A. Jivkovich, and Ye. Vapnik within the Hatrurim basin (Khesin \& Feinstein 1998-2000).

Rocks subjected to the $\mathrm{CM}$ are usually adjacent to burned fossil fuels (coal, oil shale, and oil-and-gas deposits). Most of the known CM zones are 
very young, historic to recent age (Cisowski \& Fuller 1987; Chesnokov \& Tsherbakova 1991). The Hatrurim Formation (Fm.) is a unique case as the suggested CM event is relatively old (Miocene age), and the source of heat can only be inferred.

As suggested by numerous studies (e.g. Bentor et al. 1981; Burg et al. 1991, 1999), the CM of sedimentary rocks of the Hatrurim basin was due to internal combustion of the bituminous rocks. The extensive combustion caused a hightemperature low-pressure metamorphism followed by consequent retrograde alterations (hydration, carbonization, and sulphatization). The burning was intensive and rapid, close to the Earth's surface (oxygen in access), and distributed in many local foci. However, due to unclear geological situation alternative mechanisms of metamorphism have been proposed as well, e.g. hydrothermal alteration (Gilat 1998).

In many $\mathrm{CM}$ zones magnetic investigations of the strata adjacent to the burned rocks show that the clinker, the by-product of the thermal metamorphism, is magnetic. Moreover, there are related surface anomalies characterized by high wave numbers and magnitudes of up to $500 \mathrm{nT}$ and more. In this study we examine magnetic characteristics of the Hatrurim basin and their relation to the $\mathrm{CM}$ rocks and other possible sources.

We applied the procedures that correspond to the first stage of the interpretation process (e.g. Khesin et al. 1993, 1996). A comprehensive interpretation must be completed by forward modelling and construction of physical-geological models of the studied media. Models of first approximation are required for the forward modelling. Our goal was to develop these models. Final interpretation will be possible in future, when all required data are obtained. Natural remanent magnetization (NRM) is an important required characteristic. The required NRM differs from the results of conventional palaeomagnetic investigation. During palaeomagnetic investigation, remanent magnetization of an oriented sample is determined after "cleaning" (demagnetization). Undestructed NRM is needed for calculation of effective magnetization $\left(I_{\mathrm{e}}\right)$. Such NRM determination requires special study (Khesin 1998).

\section{GEOLOGICAL SETTING}

Figure 1 shows the location of metamorphosed rocks of the Hatrurim Fm. in Israel and Jordan. The suggested bitumen-rich protolith for the Hatrirum Fm. is an Upper Cretaceous-Lower Tertiary marine chalky-marly sequence. The Hatrurim Fm. is a relatively thin ( $~ 80 \mathrm{~m}$ thick) rock complex, largely composed of low- and high-temperature metamorphic minerals (Matthews \& Gross 1980). One hundred and fourteen minerals were described in the Hatrurim Fm., of which eight were previously known only as synthetic products and five others were new minerals found only in the Hatrurim basin (Gross 1977). 


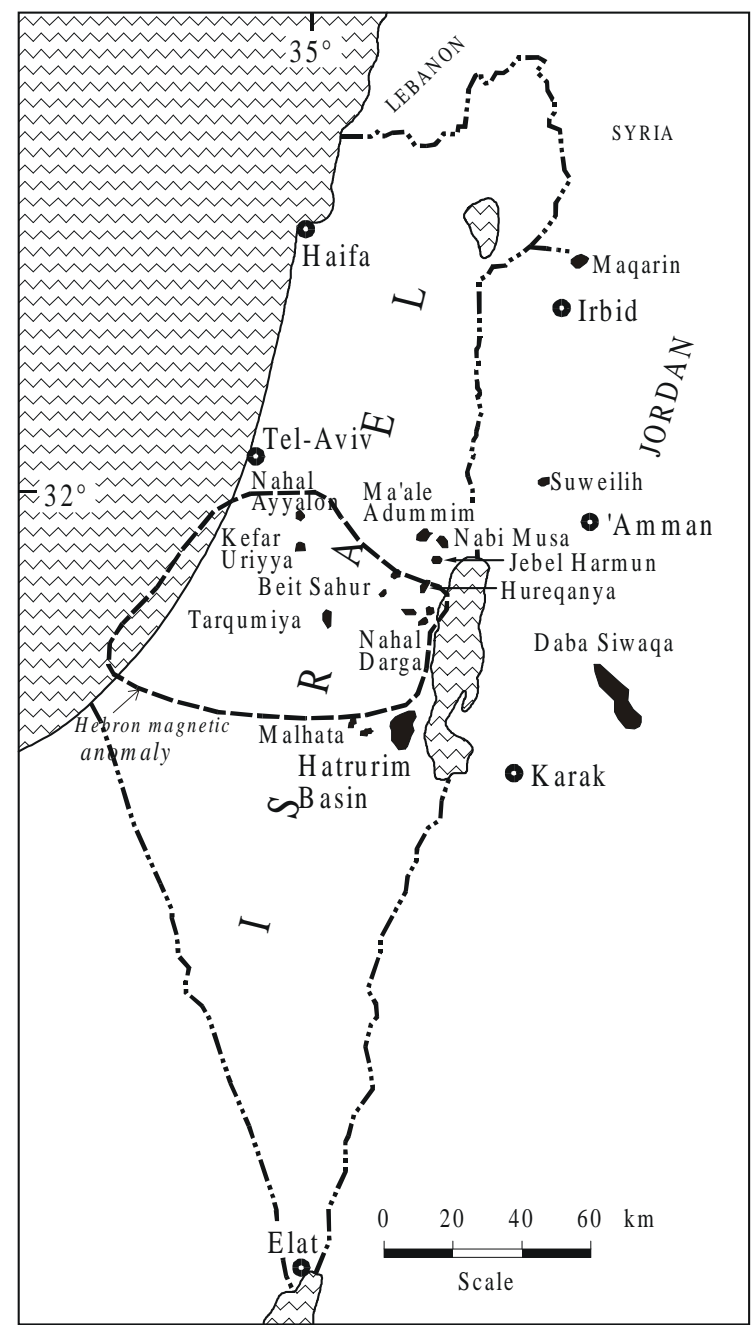

Fig. 1. Location of Hatrurim Fm. outcrops (after Burg et al. 1999, black spots) and Hebron aeromagnetic anomaly (after Rybakov et al. 1995, dashed contour).

The Hatrurim basin is a syncline with several minor structures in it (Burg et al. 1991). The main country rocks consist of dolomites, chalks, and cherts, bituminous rocks and phosphorites. Metamorphic alteration is almost completely related to rocks of the Hatrurim Fm., whereas underlying phosphorites, bitumenrich rocks, and marls, as a rule, do not show any evidence of alteration. The incipient and higher-grade metamorphism is locally found in phosphoritic rocks only, where it is expressed by decarbonization of the original francolite into fluorapatite and recrystallization (Burg et al. 1991). The metasedimentary sequence of the Hatrurim Fm. may be divided into the following units: (a) marly and chalky 
slightly altered rocks, sometimes with fossils; (b) low- and high-grade calciumsilicate rocks; (c) anorthite-diopside fels bodies showing very local and episodic distribution; and (d) retrograde rocks forming prominent weathering crust zones. Carbonates, sulphates, and zeolites are common rocks within the weathering crust.

\section{INTERPRETATION OF AEROMAGNETIC DATA}

An aeromagnetic survey at a flight altitude of $1000 \mathrm{~m}$ above sea level (Domzalsky 1967) and a 1:250 000 map (Folkman \& Yuval 1976) reveal a $7 \mathrm{~km}$ long NNE oriented zone of asymmetrical aeromagnetic anomaly with a magnitude of $20 \mathrm{nT}$ in the NW corner of the Hatrurim basin. A second, less distinctive subisometric anomaly is evident in the southern part of the Hatrurim basin (Fig. 2). The interval between flight lines of the continuous survey was about $2 \mathrm{~km}$, and the map in Fig. 2 was compiled without smoothing. Both these anomalies are obscured in the more recent 1:500 000 magnetic map (Rybakov et al. 1994), possibly due to the strong data smoothing out.

The residual aeromagnetic map and NW-SE $\Delta T$ profile A-D (Fig. 3) from the vicinity of Arad (165/75 Israel grid coordinates) to the Dead Sea (185/63 coordinates) we derived from Folkman \& Yuval (1976) data. The NNE oriented aeromagnetic anomaly is characterized by a local maximum (Fig. 3) superimposed on the southeastern slope of the regional Hebron anomaly (see Fig. 1).

The local normal geomagnetic field $T_{0}$ for the studied area is $\sim 43600 \mathrm{nT}$, the inclination angle $i_{0}$ of $T_{0}$ vector is $44^{\circ}$, declination $D$ is $3^{\circ}$. It is very difficult to determine exactly the level of normal field for individual profiles. We solved an inverse problem of magnetic prospecting for the Hatrurim local maximum in the conditions of certain limitations and lack or deficiency of required information. Therefore, we applied rapid methods developed for inverse problem solving in complicated environments (inclined medium magnetization and observation line, an unknown level of the normal magnetic field). The source body for such a local maximum may be approximated by a thin vertical or inclined bed. It is impossible to exclude a model of fold structure with a steeply dipping fold axis. However, for such a model methods for inversion in complicated environments are absent, and a model of bed is its first approximation.

Using the modifications of characteristic points and tangent methods mentioned above (Khesin et al. 1983, 1996), we calculate an average depth of the upper edge of the source body at approximately $700 \mathrm{~m}$ below survey level. Considering the about $1000 \mathrm{~m}$ flight level, and the about $400 \mathrm{~m}$ altitude of the study terrain, the top of the magnetic body is estimated to be at shallow depth (c. $100 \mathrm{~m})$ below the Earth's surface.

The use of characteristic points and tangent methods allows us also to calculate from the magnetic field data a generalized angle $\theta$. In the case of the thin bed model it is the angular difference between the body's dip angle $\left(\varphi_{2}\right)$ and 


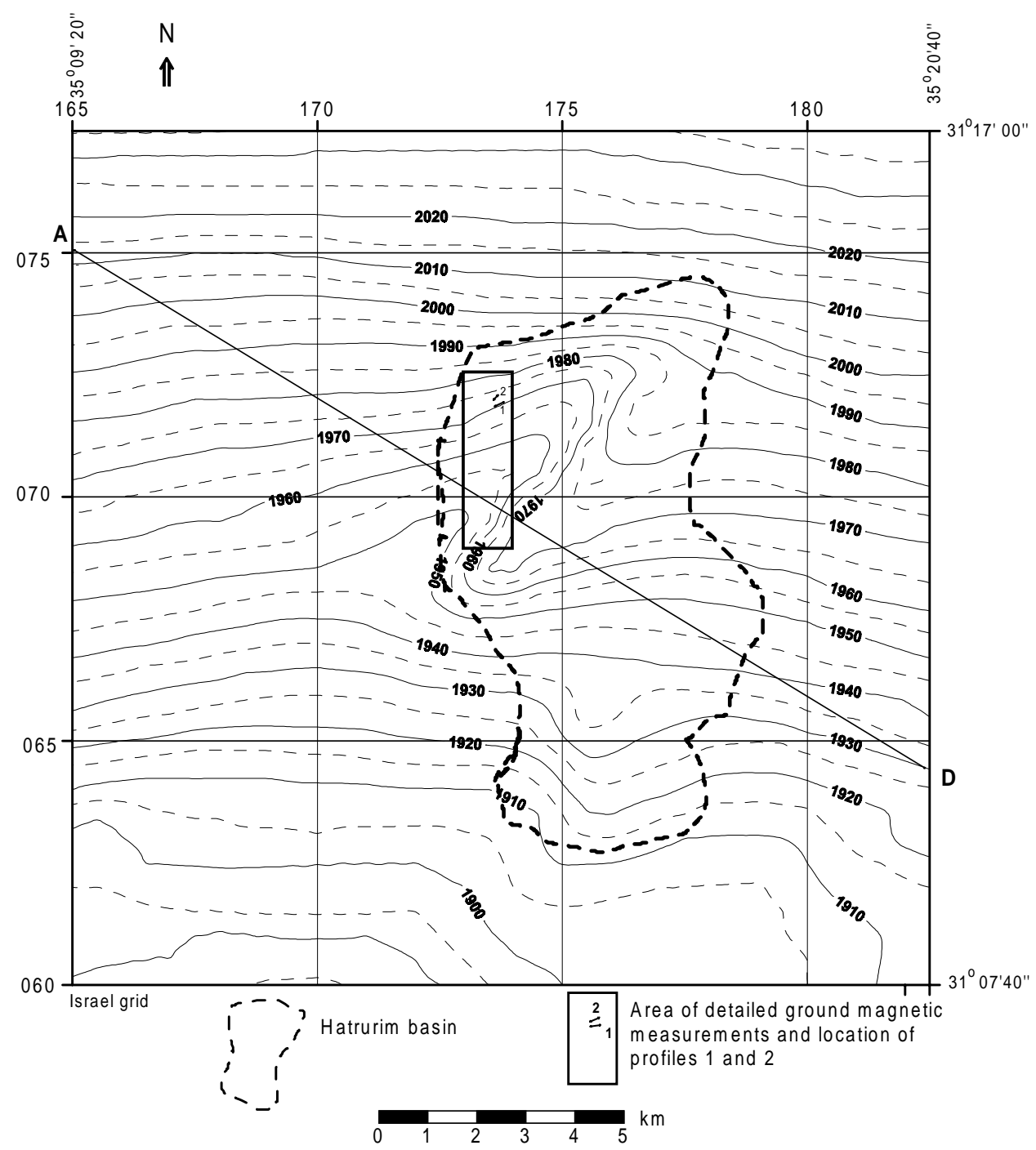

Fig. 2. Aeromagnetic anomalies of the Hatrurim basin (after Folkman \& Yuval 1976). Note: magnetic general trend reflects the trend of the regional Hebron anomaly. $\Delta T$ isolines in nanoTesla.

the direction $\left(\varphi_{\mathrm{m}}\right)$ of the effective magnetization $\left(I_{\mathrm{e}}\right)$. According to Khesin et al. (1983, fig. 4) or Khesin (1998, fig. 2), $\varphi_{\mathrm{m}}$ is the angle of inclination of magnetization projection $I_{\mathrm{xz}}$ to the horizon. The $\theta$ value obtained for the Hatrurim local aeromagnetic maximum is about $30^{\circ}$. The direction of remanent magnetization is close to the modern magnetic field (Ron \& Kolodny 1992). If $I_{\mathrm{e}}$ is concordant with the magnetized field, it is possible to calculate $\varphi_{\mathrm{m}} \approx 64^{\circ}$, and thus $\varphi_{2}$ is $\sim 94^{\circ}$ (a steeply dipping body). 


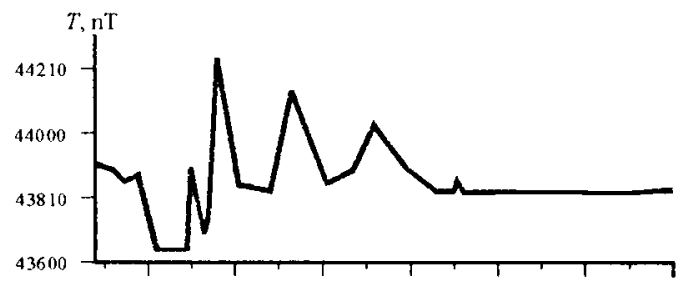

$x, n \times 10^{-5}$ un. SI

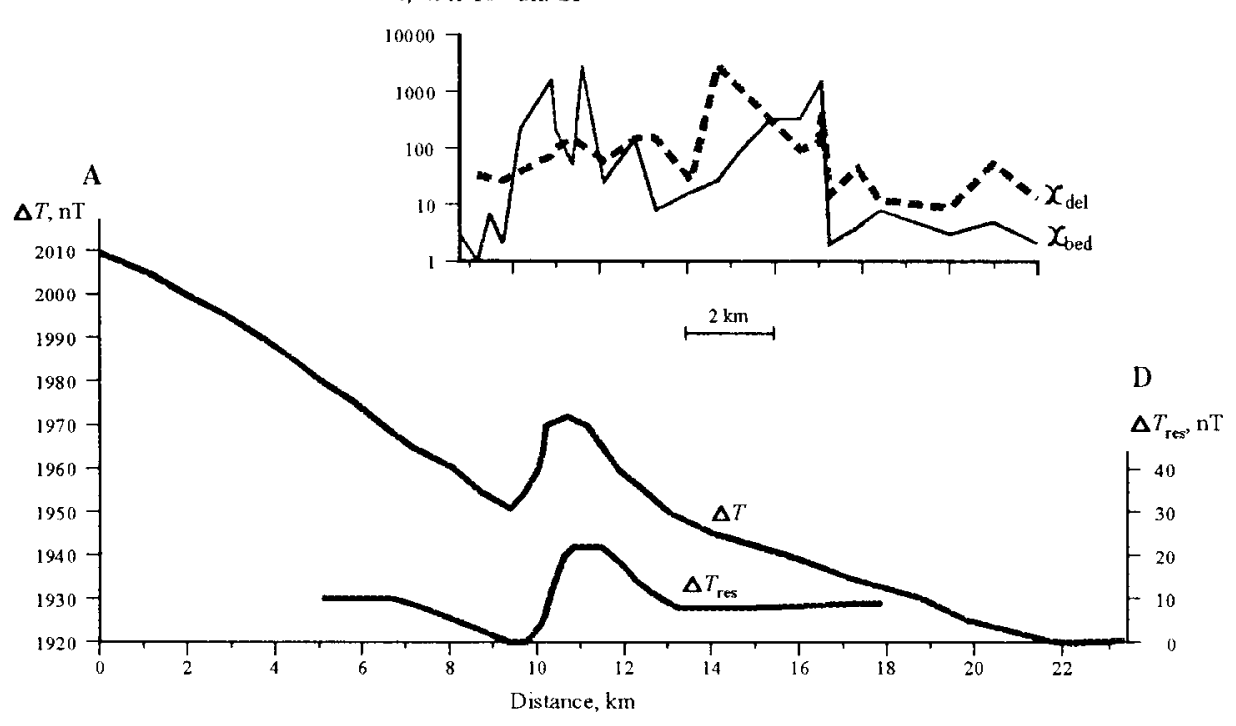

NW

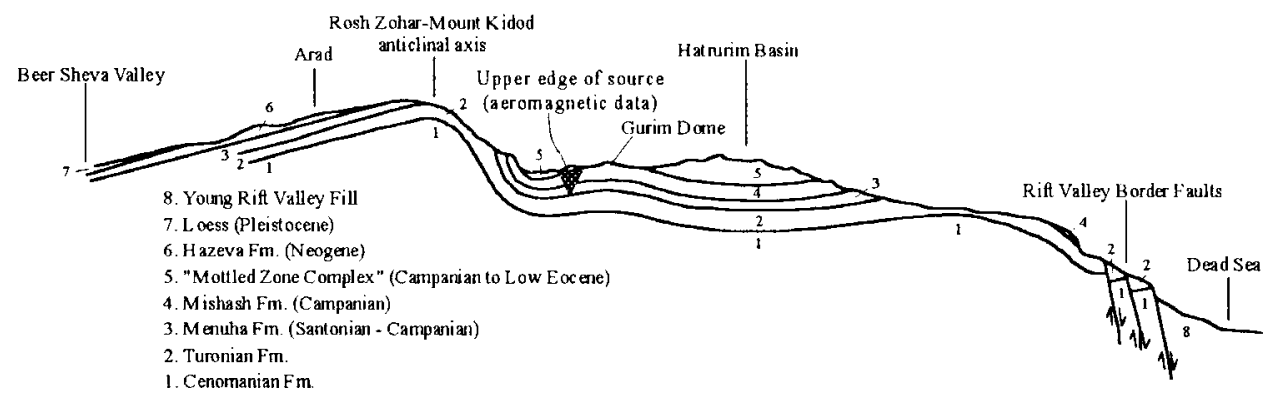

Fig. 3. Profile A-D: Ground measurements $(T, \chi)$, aeromagnetic data $\left(\Delta T, \Delta T_{\text {res }}\right)$, and the geological section (after Bentor 1966, p. 55). Vertical scale exaggeration of the geological section is 6.5. $\chi_{\text {del }}$ and $\chi_{\text {bed }}$ are magnetic susceptibilities of the overburden (deluvium, etc.) and bedrock, respectively; $\Delta T_{\text {res }}$ is the difference between the observed and averaged $\Delta T$ fields. 


\section{LARGE-SCALE GROUND EXAMINATION OF THE NNE AEROMAGNETIC ANOMALY}

Ground measurements of the magnetic field and susceptibility were performed along the profile A-D (Fig. 3) at 27 stations with an average $0.5 \mathrm{~km}$ interval between the stations. The data for $T$ were obtained using the proton magnetometer M203-M for magnetic field measurements, and the optical pump magnetometer MM-60 for registration of diurnal variations. Series of $T$ observations at every station were averaged and corrected for diurnal variations. Measurements of $\chi$ were performed by K2 (Canadian) and KT5 (Czechoslovak) magnetic susceptibility meters. The values of the measured magnetic susceptibility may be underestimated due to near-surface alteration and ragged surface of investigated rocks. Thus, the maximum value from the $\chi$ measurements at every station was selected and plotted for all ground profiles. As $\chi$ values for the overburden (mainly deluvium and eluvium) in the profile were often higher than that for bedrock outcrops, these values $\left(\chi_{\text {del }}\right.$ and $\chi_{\text {bed }}$, respectively), were plotted separately in Fig. 3 (logarithmic scale).

The ground profile A-D comprises a NW segment with a mainly low $T$ field and a central segment with a relatively high fluctuated $T$ field. Thus, the long wavelength pattern of the ground magnetic measurements is consistent with the asymmetrical $\Delta T$ residual anomaly (Fig. 3). In more detail each segment of the ground measurements comprises several short wavelength minimums and maximums of $T$ and $\chi$. High $\chi$ values (up to $2900 \times 10^{-5}$ un. SI) were observed for the Hatrurim Fm. in the area of the NNE oriented aeromagnetic anomaly. Relatively high values (up to $150 \times 10^{-5}$ un. SI) were measured in this area also for the underlying bituminous carbonates ("oil shales") and phosphates (Fig. 3), whereas elsewhere in Israel Upper Cretaceous sedimentary rocks are practically nonmagnetic (Khesin \& Feinstein 1998-2000).

\section{DETAILED GROUND MAGNETIC MEASUREMENTS}

We performed detailed ground measurements along 12 profiles in the area of the NNE oriented aeromagnetic anomaly. Due to high variability of the study medium, $T$ measurements were performed in short intervals $(2.5-5 \mathrm{~m})$. In general, the interval between $\chi$ measurement points was $5 \mathrm{~m}$. In some cases, where bedrocks were exposed along the profiles, additional measurements were carried out. The $\chi$ values obtained at various localities for the overburden and for the bedrocks are similar and therefore were integrated in the plot of the susceptibility.

Profiles 1 and 2 represent two types of spatial distributions of $T$ and $\chi$ values.

In profile 1 (Fig. 4) $T$ anomaly magnitude and $\chi$ maximum reach up to $1750 \mathrm{nT}$ and $550 \times 10^{-5}$ un. SI, respectively. The data show a varying, but generally high $T$ 

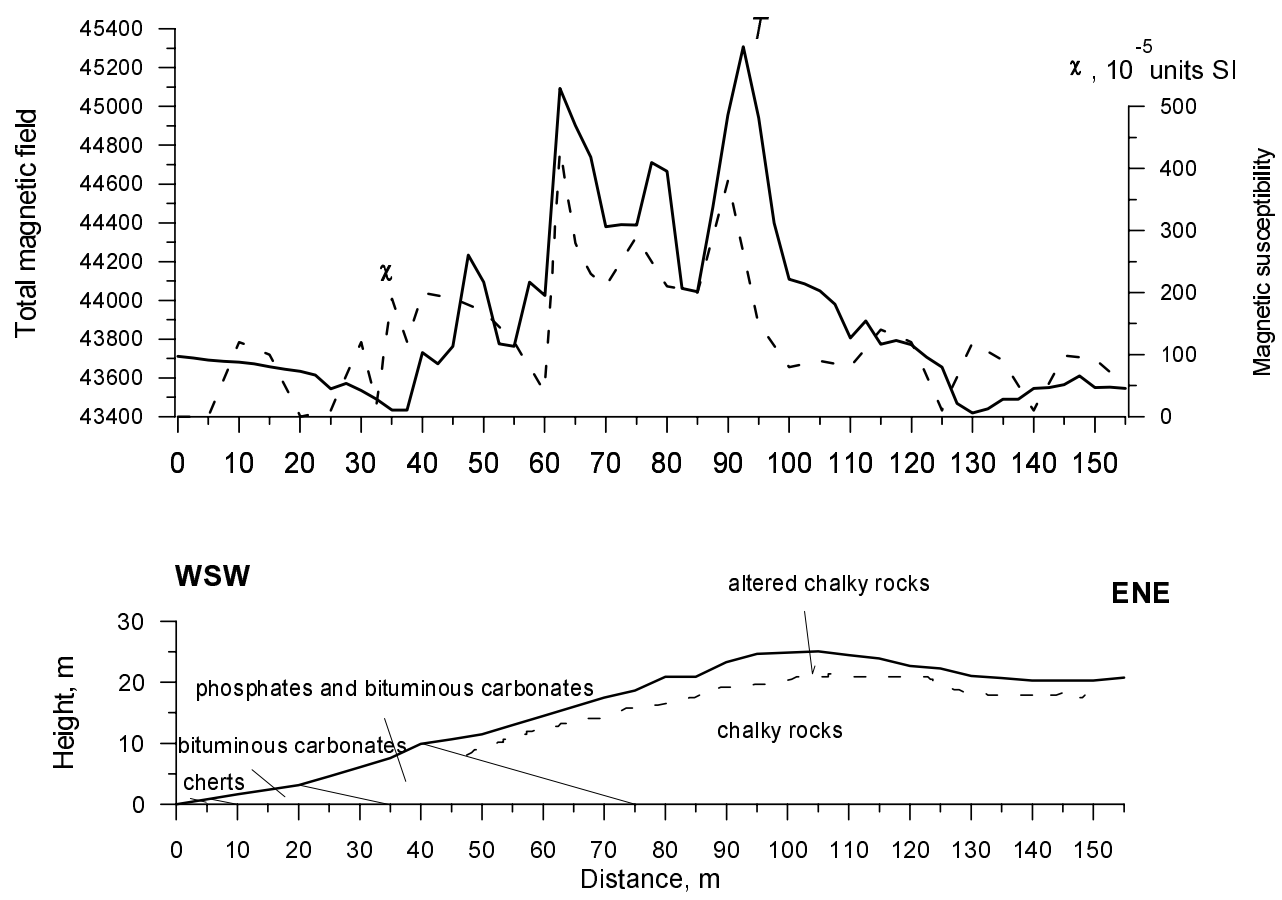

Fig. 4. Profile 1: Comparison of magnetic and geological data.

in the central part and clear minimums and smooth magnetic fields on both sides of the profile. Likewise, the magnetic susceptibility is relatively high in the central part and low on both sides. Increased values of $T$ and $\chi$ coincide with the outcrop of altered chalky rocks of the Hatrurim Fm. Relatively high $\chi$ values at the intervals of nonmagnetic bituminous carbonates and phosphates are due to the deluvium derived from the Hatrurim Fm. rocks. Sometimes, local magnetic maximums were observed within intervals of minor altered chalks containing still well preserved fossils (pickets $70 \mathrm{~m}$ and $90 \mathrm{~m}$ ). The variations in $\chi$ in relation to different rock layers can only account for the $T$ peculiarities within the main part of the anomaly. In several cases local $T$ maximums do not correspond to $\chi$ maximums. In addition, the magnitude of most magnetic anomalies is higher than could have been anticipated for the related magnetic susceptibility. Thus, the magnetic field profile possibly reflects an integrated effect of the near-surface alternation of magnetic and nonmagnetic beds and a respectively large hidden magnetic body, or high remanent magnetization.

For the characterization of the inferred hidden body we applied the method of characteristic areas (Khesin et al. 1983, 1996). The method allows of the calculation of the depth $(h)$ to the centre of a cylindrical model body and its effective magnetic moment $\left(M_{\mathrm{e}}\right)$. The basic parameter $(Q)$ of this method is: 


$$
Q=\int_{\chi_{\max }}^{\chi_{\min }}\left(\Delta T-\Delta T_{\min }\right) d x,
$$

where $\chi_{\min }$ and $\chi_{\max }$ are the abscissas of the minimum $\left(\Delta T_{\min }\right)$ and maximum $\left(\Delta T_{\max }\right)$ of the magnetic anomaly, respectively; $\Delta T=T-T_{0}$.

The $Q$ value does not depend on the level of the normal field and location of the origin of coordinates. According to Eq. (1), the $Q$ value in the interval of $35-90 \mathrm{~m}$ of profile 1 is $52300 \mathrm{nT} \cdot \mathrm{m}$. From the $Q$ value and the generalized angle $\theta$ obtained we calculate:

$$
h=1.8 Q / \Delta T_{\mathrm{A}}
$$

and

$$
M_{\mathrm{e}}=1.3 Q^{2} / \Delta T_{\mathrm{A}},
$$

where $\Delta T_{\mathrm{A}}$ is the magnitude of magnetic anomaly $\left(\Delta T_{\mathrm{A}}=T_{\max }-T_{\min }=\Delta T_{\max }-\right.$ $\left.\Delta T_{\text {min }}\right)$.

According to Eqs. (2) and (3), the $h$ value is about $50 \mathrm{~m}$ and $M_{\mathrm{e}}$ is about $1550000 \mathrm{nT} \cdot \mathrm{m}^{2}$. For the study model $M_{\mathrm{e}}$ is given by the expression (Khesin et al. 1996)

$$
M_{\mathrm{e}}=I_{\mathrm{e}} C_{0} C_{\mathrm{m}} S,
$$

where $C_{0}=\sin i_{0} / \sin \varphi_{0}, C_{\mathrm{m}}=\sin i_{\mathrm{m}} / \sin \varphi_{\mathrm{m}}, S$ is the cross-section area of the body, $i_{0}$ is the inclination angle of the normal geomagnetic field $\left(T_{0}\right)$ vector, $\varphi_{0}$ is the angle of inclination between the geomagnetic-field-vector projection on the plane of profile $\left(T_{0}\right)_{\mathrm{xz}}$ and the horizon, $i_{\mathrm{m}}$ is the inclination angle of the magnetization vector to the horizon, $\varphi_{\mathrm{m}}$ is the angle of inclination of magnetization projection $I_{\mathrm{xz}}$ to the horizon (see fig. 4 in Khesin et al. 1983 or fig. 2 in Khesin 1998).

From this figure it followed that

$$
\cot \varphi_{0}=\cot i_{0} \cos \delta_{0}
$$

where $\delta_{0}$ is the difference between the azimuth of $T_{0}$ and the $O x$ axis.

Then $\varphi_{0}$ is $70.5^{\circ}$. As was noted above, it is possible to assume that the body is magnetized in accordance with the present-day geomagnetic field. Then $i_{\mathrm{m}}=i_{0}=44^{\circ}, \varphi_{\mathrm{m}}=\varphi_{0}=70.5^{\circ}$. Thus, $C_{0}=0.738, C_{\mathrm{m}}=C_{0}=0.738$.

Let us consider a limiting case for the radius of the source body. The maximum value of the radius would be equal to the cylinder depth centre. In this case, the model cylinder touches the Earth's surface. In other words, it is suggested that the rocks outcropping here are more distributed at depth. Then, $S=7850 \mathrm{~m}^{2}$, and $I_{\mathrm{e}} \approx 360 \mathrm{~mA} / \mathrm{m}$ according to Eq. (4). It is a minimum possible value of effective magnetization of the source body: if the cylinder radius is smaller, then the $I_{\mathrm{e}}$ value will be greater (see Eq. (4)). 
To evaluate the magnetic susceptibility of the source body, we were obliged to neglect the remanent magnetization, although its intensity varies from low values up to $6 \mathrm{~A} / \mathrm{m}$ (Ron \& Kolodny 1992). However, these values were obtained during palaeomagnetic study with demagnetization of samples, and do not represent modern magnetization. Thus, we assume $I_{\mathrm{e}} \approx I_{\mathrm{i}}$ (induced magnetization). As $I_{\mathrm{i}}=\chi T_{0}$ and the magnetizing field $T_{0}$ is $\sim 43600 \mathrm{nT}$, the $\chi$ value of the hidden body is about $850 \times 10^{-5}$ un. SI. Possible decrease in the value because of the NRM effect is somewhat compensated by the above-noted effect of a possible decrease in the body radius.

In profile 2 (Fig. 5), the $T$ anomaly magnitude and $\chi$ maximum reach up to $1500 \mathrm{nT}$ and $870 \times 10^{-5} \mathrm{un}$. SI, respectively, over the outcrop of altered chalky rocks. The southern part of the profile shows a relatively constant field level, whereas there are substantial short wavelength fluctuations in the northern part.

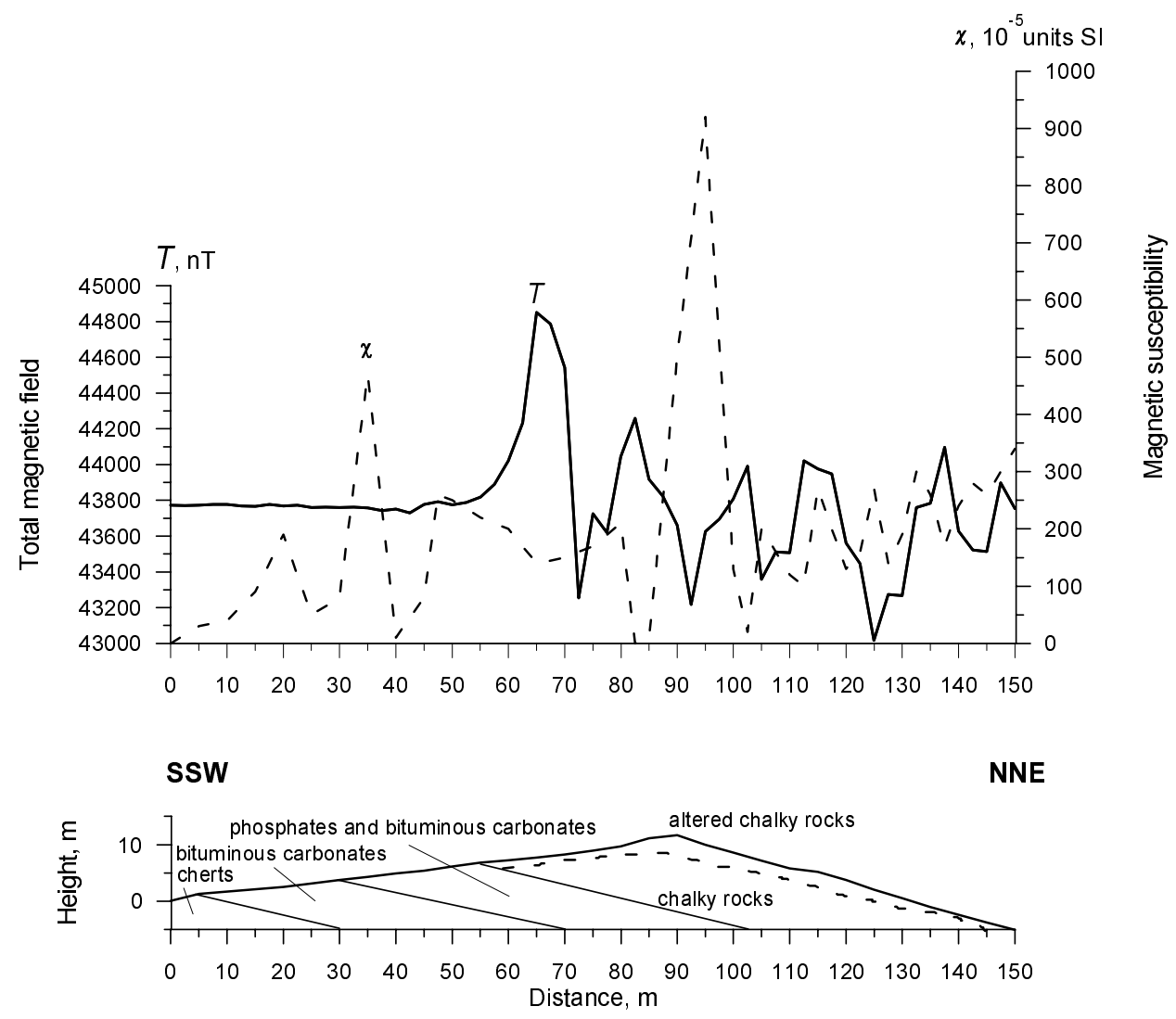

Fig. 5. Profile 2: Comparison of magnetic and geological data. 
This field pattern reflects the lateral transition between the nonmagnetic bituminous carbonates and phosphates (Mishash Fm.) in the south and interstratification of magnetic and nonmagnetic near-surface beds (Hatrurim Fm.) in the north. However, the local short-wave magnetic anomalies in the northern part of the profile cannot be explained by the lateral inhomogeneities in the Hatrurim rocks and are possibly related to the effect of the suggested subvertical beds. Like in profile 1 , the increased $\chi$ values in the intervals of nonmagnetic bituminous carbonates and phosphates are due to magnetic deluvium. Here, again, the local magnetic maximum (picket $65 \mathrm{~m}$ ) was observed within an interval of weak alteration where fossils are still well preserved. Despite the higher $\chi$ values for the rocks outcropping in the northern part, the mean level of the fluctuating field is here lower than the relatively constant field in the northern part. This probably reflects a closer proximity of the northern part of profile 2 to a postulated hidden body in the south and its minimum magnetic field effect.

\section{DISCUSSION}

Very detailed ground magnetic profiles within the NW Hatrurim basin reveal significant $\chi$ variations for the Hatrurim Fm. rocks (Fig. 6, Table 1). Underlying unaltered formations are usually nonmagnetic. By and large, the $\chi$ values appear to show correlation with the distribution of the Hatrurim Fm. (Table 1). The $T$ values show a similar correlation. However, in closer examination these relationships are often more complex and in some cases do not exist. Neither the $T$ nor the $\chi$ values appear to show correlation with the level of metamorphic alteration. Some of the magnetic anomalies were recorded over mildly altered and unaltered rocks, whereas highly altered rocks may show low $\chi$ values. Likewise, Ron \& Kolodny (1992) show that there is also no correlation between the metamorphic grade of the Hatrurim Fm. and the NRM.

Profile A-D (Fig. 3) further demonstrates displacement of the local aeromagnetic anomaly with respect to the thickness of the Hatrurim rocks. The weak relation between magnetic characteristics and thickness and/or metamorphic grade of altered rocks distinguishes the Hatrurim basin from other CM regions. Cisowski \& Fuller (1987) noted a good correlation between NRM and metamorphic grade of the rocks in CM zones in California and of currently burning bituminous shales along the shore of the Beaufort Sea in Canada. Bentor et al. (1981) showed a correlation between magnetic anomalies and rocks susceptibility, and between both parameters and the metamorphic grade in the Monterey and Sisquoc shales in southern California.

The poor correlation between the magnetic characteristics and distribution of altered rocks, and the only partial account for the $T$ anomalies by the $\chi$ values in the Hatrurim basin lead us to some suggestions. The Hatrurim section is subhorizontally layered with lateral variations. Nevertheless, the magnetic field 

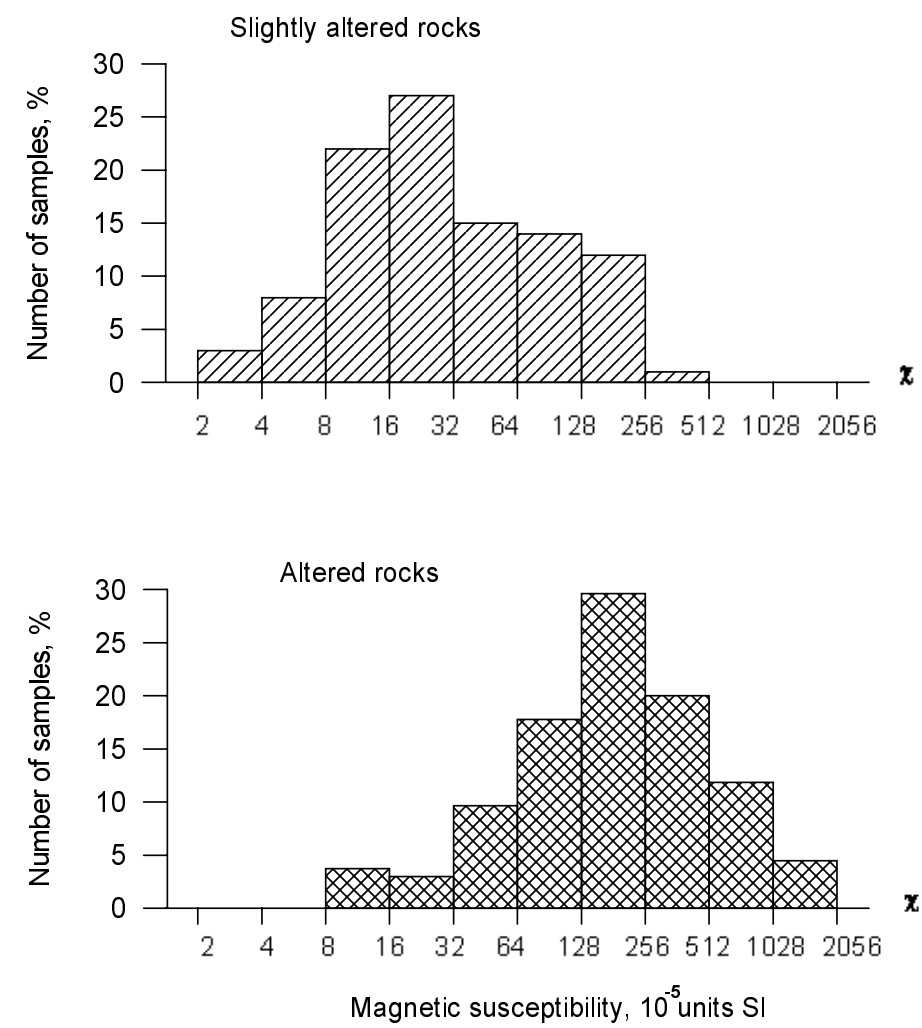

Fig. 6. Histograms of $\chi$ values for slightly altered and altered rocks of the Hatrurim Fm..

Table 1. Magnetic susceptibility of bedrock and overburden

\begin{tabular}{|c|c|c|c|c|}
\hline \multirow[t]{2}{*}{ Geological unit } & \multirow{2}{*}{$\begin{array}{c}\text { Number of } \\
\text { observations }\end{array}$} & \multicolumn{3}{|c|}{ Magnetic susceptibility, $10^{-5}$ un. SI } \\
\hline & & Minimum & Maximum & Average \\
\hline \multicolumn{5}{|l|}{ Hatrurim Fm. } \\
\hline Slightly altered rocks & 110 & 0 & 340 & 47 \\
\hline Altered rocks & 135 & 9 & 1800 & 291 \\
\hline Fels & 22 & 28 & 4000 & 1033 \\
\hline Ferruginous concretions & 17 & 40 & 3700 & 1484 \\
\hline \multicolumn{5}{|l|}{$\begin{array}{l}\text { Overburden (loose deposits), } \\
\text { recycled Hatrurim Fm. }\end{array}$} \\
\hline Slightly altered rocks & 29 & 15 & 90 & 38 \\
\hline Altered rocks & 91 & 22 & 326 & 118 \\
\hline \multicolumn{5}{|l|}{ Mishash Fm. } \\
\hline Phosphates, carbonates & 62 & 0 & 37 & 4 \\
\hline Altered rocks & 28 & 51 & 148 & 34 \\
\hline $\begin{array}{l}\text { Overburden (loose deposits), } \\
\text { recycled Mishash Fm. }\end{array}$ & 28 & 17 & 51 & 36 \\
\hline
\end{tabular}


and susceptibility pattern recorded by ground measurements reflect both lateral and pronounced subvertical inhomogeneities. This coexistence of lateral and vertical components is supported by measurements of vertical $T$ gradients at several points along the A-D profile. Normal attenuation of the magnetic field with the increase in the vertical distance of the sensor from the Earth's surface was recorded for some points and indicates a deep subvertical source effect. Changes of vertical gradient sign recorded for other points revealed a component of lateral influence.

A combination of methods of inverse problem solution for the Hatrurim local aeromagnetic maximum corroborates a relatively shallow subvertical source body. The rapid decline of the magnetic anomaly magnitude from $10^{2}-10^{3} \mathrm{nT}$ in ground measurements to $\sim 20 \mathrm{nT}$ in aeromagnetic survey at about $600 \mathrm{~m}$ clearance suggests that the source body is a relatively thin shallow bed. Thus, considering the geometrical approximation, we infer that the magnetic source may be a dykelike intrusion or fault zone. The Hatrurim local aeromagnetic maximum appears as a single anomaly because of the high clearance of the survey and smoothing of the observed field due to flight speed. In a large-scale ground examination the aeromagnetic single anomaly disintegrates into several extremums, which probably reflect few magnetic bodies.

The detailed ground profiling reveals both short wavelength anomalies superimposed on relatively wide wavelength $T$ anomalies. The larger-scale anomalies possibly reflect relatively large hidden bodies. Inversion of ground magnetic anomaly at profile 1 also shows the possible presence of a relatively large body with $\chi$ about $850 \times 10^{-5}$ un. SI at a shallow depth of a few tens of metres. Such a $\chi$ value is in the range usually characterizing intermediate or slightly serpentinized ultrabasic igneous rocks. This analysis further shows that the source for the short wavelength anomalies is a series of near-surface interstratified very thin nonmagnetic and magnetic beds.

The Hatrurim local aeromagnetic maximum is situated at the periphery of the Hebron aeromagnetic anomaly. Most of the Hatrurim Fm. outcrops in Israel are located either within this anomaly region or at its periphery (see Fig. 1). Hatrurim Fm. outcrops in Jordan (Fig. 1) are also situated adjacent to magnetic anomalies (cf. Rybakov et al. 1994). Although the age assumed for the inferred intrusive rocks causing the Hebron magnetic anomaly is relatively old (Early Mesozoic, Rybakov et al. 1995), it is possible that the areas of altered rocks evolved in genetic relation to the intrusion and might indicate some rejuvenation of igneous phases concentrated along its margins.

\section{CONCLUSIONS}

Interpretation of aeromagnetic data and ground magnetic profiling within the Hatrurim basin revealed a series of particularities. 
1. Clear narrow asymmetrical aeromagnetic anomaly with a length of about $7 \mathrm{~km}$ possibly reflects a steeply inclined bed whose upper edge is located near the Earth's surface.

2. In general, the long wavelength pattern of large-scale ground magnetic measurements along the Arad-Dead Sea profile is consistent with the asymmetrical aeromagnetic anomaly. Relatively high $\chi$ values for both Hatrurim Fm. and underlying bituminous carbonates and phosphates can be related to an endogenic influence.

3. Detailed ground magnetic prospecting in the vicinity of the asymmetrical aeromagnetic anomaly shows that altered rocks of the Hatrurim Fm. in the NW Hatrurim basin are characterized by $\Delta T$ anomalies of up to $4000 \mathrm{nT}$ with high wave numbers and increased $\chi$ values of up to $4000 \times 10^{-5}$ un. SI. The relation between metamorphic grade and magnetic properties of the Hatrurim Fm. is unclear. Whilst geological data indicate the lateral character of alteration, the field pattern reflects a combination of near-surface alternation of subhorizontal magnetic and nonmagnetic thin beds, local thin subvertical beds and a subvertical, relatively large hidden magnetic body.

Thus, the obtained magnetic characteristics are difficult to relate to the $\mathrm{CM}$ process only. Metamorphic processes were more complicated and probably related to the superposition of several events. Magnetic intrusive or altered rocks at depth may be suggested. Therefore, some high-temperature alteration of carbonate rocks may be related to endogenic activity (magmatic or hydrocarbon fluids?).

The structure and origin of altered rocks within the basin, form of iron, nature and type of magnetic minerals, dimensions and spatial distribution of magnetic grains require further integrated study. It is likely that important information on near-surface peculiarities of the Hatrurim Fm. could be obtained through the integration of magnetic (including NRM and anisotropy) studies with gammaspectrometry. The induced polarization sounding and profiling may be applied for the evaluation of the composition (content of iron sulphides or oxides) and depth of subsurface bodies.

The present article describes the first experience of quantitative interpretation of magnetic anomalies within the Hatrurim basin. It is obvious that further more comprehensive interpretation will require physical-geological modelling with utilization of medium characteristics that were obtained now and will be available after performing the recommended works. Special attention must be spared to the $I_{\mathrm{e}}$ determination. It is impossible to apply here the correlation method because of high heterogeneity of the studied medium. Thus, two ways of undestructed NRM evaluation could be used: (a) measurements of large oriented samples by a component magnetometer; and (b) application of conventional palaeomagnetic techniques, but without sample demagnetization. 


\section{ACKNOWLEDGEMENTS}

The study was supported by the Earth Science Research Administration, Ministry of National Infrastructures of Israel (grant No. 98/99-17-009). The authors are very grateful to S. Feinstein, A. Jivkovich, and Ye. Vapnik for their assistance in fieldwork and fruitful discussions.

\section{REFERENCES}

Bentor, Y. K. 1966. The Clays of Israel, Guide-Book to the Excursions. The International Clay Conference. Jerusalem.

Bentor, Y. K., Kastner, M., Perlman, I. \& Yellin, Y. 1981. Combustion metamorphism of bituminous sediments and the formation of melts of granitic and sedimentary composition. Geochim. Cosmochim. Acta, 45, 2229-2255.

Burg, A., Starinsky, A., Bartov, Y. \& Kolodny, Y. 1991. Geology of the Hatrurim Formation ("Mottled Zone") in the Hatrurim basin. Israel J. Earth Sci., 40, 107-124.

Burg, A., Kolodny, Y. \& Lyakhovsky, V. 1999. Hatrurim - 2000, The "Mottled Zone" revisited, forty years later. Israel J. Earth Sci., 48, 209-223.

Chesnokov, B. V. \& Tsherbakova, E. P. 1991. The Mineralogy of Burned Heaps in the Chelyabinsk Coal Basin. Nauka, Moscow.

Cisowski, S. M. \& Fuller, M. 1987. The generation of magnetic anomalies by combustion metamorphism of sedimentary rock, and its significance to hydrocarbon exploration. Geol. Soc. Am. Bull., 99, 21-29.

Domzalsky, W. 1967. Aeromagnetic survey of Israel. Inst. Petr. Res. and Geoph. Unpubl. Rep. AMS/482/67.

Folkman, Y. \& Yuval, Z. 1976. Aeromagnetic map, $1: 250,000$. Survey of Israel.

Gilat, A. 1998. Hydrothermal activity and hydro-explosions as a cause of natural combustion and pyrolysis of bituminous rocks: the case of Pliocene metamorphism in Israel (Hatrurim Formation). Geol. Surv. Isr. Current Res., 11, 96-102.

Gross, Sh. 1977. The mineralogy of the Hatrurim Formation, Israel. Geol. Surv. Israel. Bull., 70.

Khesin, B. 1998. Effective magnetization of the Precambrian in Sinai and southern Israel: implication of new methods for $\Delta T$ field analysis. Israel J. Earth Sci., 47, 47-60.

Khesin, B. E., Alexeyev, V. V. \& Metaxa, Kh. P. 1983. The Interpretation of Magnetic Anomalies Under Oblique Magnetization and Rugged Topography. Nedra, Moscow.

Khesin, B., Alexeyev, V. \& Eppelbaum, L. 1993. 3-D modeling of gravity and magnetic fields as a final stage of application of effective interpretation system of geophysical data under difficult geological conditions. GeoInformatics, 4, 85-96.

Khesin, B., Alexeyev, V. \& Eppelbaum, L. 1996. Interpretation of Geophysical Fields in Complicated Environments. Kluwer Academic Publishers, Dordrecht.

Khesin, B. \& Feinstein, S. 1998, 1999, 2000. Correlation analysis of measured magnetic field and determinations of Phanerozoic rock magnetization in southern Israel. Reports for Earth Sciences Research Administration, Ministry of Infrastructure: ES-15-98, ES-24-99, and ES-24-00

Matthews, A. \& Gross, S. 1980. Petrologic evolution of the "Mottled Zone" (Hatrurim) Metamorphic Complex of Israel. Israel J. Earth Sci., 29, 93-106.

Ron, H. \& Kolodny, Y. 1992. Paleomagnetic and rock magnetic study of combustion metamorphic rocks in Israel. J. Geoph. Res., 97, 6927-6939.

Rybakov, M., Goldshmidt, V., Folkman, Y., Rotstein, Y., Ben-Avraham, Z. \& Hall, J. 1994. Magnetic Anomaly map, 1:500,000. Survey of Israel.

Rybakov, M., Fleisher, L. \& Goldshmidt, V. 1995. A new look at the Hebron magnetic anomaly. Israel J. Earth Sci., 44, 41-49. 


\title{
Aeromagnetilise anomaalia maapealne vaatlus muutunud settekivimite alal (Hatrurimi bassein, Iisrael)
}

\author{
Boris Khesin ja Sophia Itkis
}

\begin{abstract}
Aeromagnetilise mõõdistamisega avastati Hatrurimi basseinis kaks lokaalanomaaliat intensiivsusega kuni $20 \mathrm{nT}$. Seal on laialt levinud Hatrurimi kihistu (peamiselt karbonaatsed) settekivimid (ülemkriit-eotseen). Arvatakse, et nende kivimite moone on bituminoossete karbonaatsete kivimite ("põlevkivi") maapealse põlemise tulemus. Ulatusliku $(\mathrm{ca} 7 \mathrm{~km})$ aeromagnetilise anomaalia allikaks võib olla õhuke järsu kallakuga kiht, mille ülemine pind on maapinna lähedal. Detailne maapealne magnetiline mõõdistamine tõi esile kõrgsageduslikud anomaaliad intensiivsusega kuni $4000 \mathrm{nT}$ ja moondunud kivimite suure magnetilise vastuvõtlikkuse (kuni $4000 \times 10^{-5} \mathrm{SI}$ ). Need efektid on seostatavad pindmisel põlemisel tekkinud lateraalsete muutustega. Vaadeldud magnetväli kajastab nii subhorisontaalsete maapinnalähedaste magnetiliste ja mittemagnetiliste õhukeste (mõni meeter) kihtide vaheldumise kui ka õhukeste subvertikaalsete kihtide ja suhteliselt suurte (kümned meetrid) varjatud kehade mõju. Magnetiliste anomaaliate intensiivsuse ja Hatrurimi kihistu kivimite magnetilise vastuvõtlikkuse väärtuste korrelatsioon kivimite metamorfismiastmega ning anomaaliate intensiivsuse korrelatsioon moondunud kivimite paksusega on väike. Seetõttu võib pidada võimalikuks ka täiendavaid, endogeenseid moondeallikaid (magmatism või süsivesinikkude vool piki murranguid).
\end{abstract}

\section{Наземная проверка аэромагнитных данных в районе развития измененных осадочных пород (бассейн Хатрурим, Израиль)}

\author{
Борис Хесин и Софья Иткис
}

Аэромагнитная съемка выявила две локальные $T$ аномалии с амплитудой до 20 нТл в районе широкого распространения измененных осадочных (преимущественно карбонатных) пород формации Хатрурим (верхний мелэоцен). Считается, что метаморфизм этих пород обусловлен горением на дневной поверхности битуминозных карбонатов («горючих сланцев»). Интерпретация протяженной (около 7 км) аэромагнитной аномалии показала, что ее источником может быть относительно тонкий крутопадающий пласт с верхней кромкой близ дневной поверхности. Наше детальное наземное профилирование выявило высокочастотные $T$ аномалии с амплитудой до 4000 нТл и повышенные значения магнитной восприимчивости $(\chi)$ измененных пород (до $4000 \times 10^{-5}$ ед. СИ). Эти эффекты могут быть связаны с 
латеральными изменениями в результате поверхностного горения. Однако наблюдаемое магнитное поле отражает как близповерхностное переслаивание субгоризонтальных магнитных и немагнитных тонких (первые метры) пластов, так и субвертикальные магнитные маломощные пласты и относительно крупные (десятки метров) скрытые тела. Кроме того, внутри формации Хатрурим значения $T$ и $\chi$ слабо коррелируют со степенью метаморфизма, а аномалии $T-$ с мощностью измененных пород. Следовательно, наряду с принятым взглядом на формацию Хатрурим можно допустить дополнительные, эндогенные источники метаморфизма (магматизм или поток углеводородов по зонам разлома). 